\title{
LUT
}

Lappeenranta

University of Technology

\section{The Internationalisation of New Russian Ventures: The Institutional Frontier}

Laine Igor, Kuivalainen Olli

This is a Author's accepted manuscript (AAM) version of a publication published by Palgrave Macmillan, Cham

in Growth Frontiers in International Business. The Academy of International Business.

DOI: 10.1007/978-3-319-48851-6_7

Copyright of the original publication: (c) The Author(s) 2017

Please cite the publication as follows:

Laine I., Kuivalainen O. (2017) The Internationalization of New Russian Ventures: The Institutional Frontier. In: Ibeh K., Tolentino P., Janne O., Liu X. (eds) Growth Frontiers in International Business. The Academy of International Business. Palgrave Macmillan, Cham p. 121-141. DOI: 10.1007/978-3-319-48851-6_7 


\title{
Internationalisation of new Russian ventures: the institutional frontier
}

Igor Laine and Olli Kuivalainen

\begin{abstract}
Based on the view that re-engineering and upgrading the institutional environment in previous command economies offers an important new frontier for boosting new venture creation and entrepreneurial internationalisation, the current study examines and addresses institutional constraints to the internationalization of new ventures in Russia. It draws on 213 interviews with entrepreneurs and government officials, specifically regarding their perceptions and experiences of the impact of Russian institutional environment on entrepreneurial growth and internationalization. The study illuminates and discusses critical impediments to the growth and internationalization of new Russian ventures, providing practice-based insights on how the internationalisation of entrepreneurial ventures might be facilitated through improvements in institutional environment.
\end{abstract}

\section{Introduction}

Although institutional transition evolves differently in previously command economies, in general the liberalization of markets led to the increasing role of entrepreneurship, while economic globalization opens up opportunities for entrepreneurial internationalization from these countries. As far as entrepreneurship and its internationalization only recently became a legitimate form of activity in these countries, the release of their currently untapped potential for economic growth is largely dependent on adequate institutional development in these countries. Russia is a critical example of a country where levels of entrepreneurial activity and internationalization are far below comparative countries (Singer, Amorós, and Moska 2015; Verkhovskaia and Dorokhina 2014) and the levels the country could and should achieve in order to be competitive in global economy. This 
study argues that institutional environment was and still is a major reason for this problem, and thus a tailor-made institutional re-engineering is an important new frontier for boosting new venture creation and entrepreneurial internationalisation. In order to understand how institutional environment hinders the internationalization of new Russian ventures, one should consider how decision-makers perceive it. Accordingly, this study explores institutional constraints to the internationalization of new ventures in Russia based on the experience of entrepreneurs.

\section{Economic growth, institutions and entrepreneurship in Russia}

Initially, the transition of Russian economy toward freer markets was fast, radical and aggressive, but in recent years, the country partially retreated from the course showing increasing role of the government in the economy. Economic liberalization of emerging markets has given a growth impulse for Russian economy and after the August 1998 financial crisis, backed by devaluated currency, rising commodity prices, consumer boom and ongoing liberal reforms, the country`s development was at outstripping rate. The subsequent global financial crisis of 2008 was sharp for the country, but brief due to proactive and timely measures by the government and central bank. Starting from 2009 the country has shown an impressive recovery and in 2012, according to Financial Times's economic performance estimate based on seven indicators, was ranked number two among G20 (Atkins 2012). Although, starting from 2013 the growth of the economy has slowed down reaching zero levels in 2014 and $-3.7 \%$ in 2015.

In relation to international trade, membership in the World Trade Organization since August 2012 implies gradual decrease in trade barriers for cross-border trade providing certain stimuli for entrepreneurial internationalization. Additionally, establishment of Eurasia Economic Union with four neighboring countries is another facilitating factor. At the same time, devaluation of national currency makes export and sourcing from Russia an attractive opportunity for international 
entrepreneurship. On the other hand, sanction imposed by and towards multitude of western economies since spring 2014 hinders international trade possibilities for certain categories of goods as well as access to global financial markets. While Western sanctions were meant to influence a limited list of political figures and large state-affiliated business entities, their impact has a major bandwagon effect and intensified challenges that Russian economy was already facing.

According to recent report of Organization for Economic Cooperation and Development, the role of entrepreneurship in Russia on economy of the country is relatively small compared to other OECD countries in terms of numbers of enterprises, employment figures, generated output and investments (OECD 2015). Likewise, Global Entrepreneurship Monitor indicates that in 2014 just $2.4 \%$ of adults was involved in venture creation activities, that is far below other efficiency-driven economies; also only $27 \%$ of adult population perceived good opportunities for starting a business in Russia (Singer, Amorós, and Moska 2015). It has been found that development of entrepreneurship in Russia is largely hindered by the weakness of its formal institutions, such as property rights and contract enforcement (Aidis, Estrin, and Mickiewicz 2008; Alon and Rottig 2013). Various rankings such World Bank Doing Business shed their view on how easy or difficult it is for a local entrepreneur to start and operate their business across countries, putting emphasis on assessment of business regulations. For example, according to Doing Business data, from 2009 Russia to 2015 (see Table 1) has dramatically improved the overall ranking, but has not achieved any results with trading across borders (World Bank 2016).

Table 1. Russia's World Bank Doing Business rankings (out of 189 economies)

\begin{tabular}{lcccccccc}
\hline Year & $\mathbf{2 0 0 9}$ & $\mathbf{2 0 1 0}$ & $\mathbf{2 0 1 1}$ & $\mathbf{2 0 1 2}$ & $\mathbf{2 0 1 3}$ & $\mathbf{2 0 1 4}$ & $\mathbf{2 0 1 5}$ & $\mathbf{2 0 1 6}$ \\
\hline Eanking & 120 & 116 & 123 & 120 & 112 & 92 & 62 & 51 \\
Trading across borders & 161 & 162 & 162 & 160 & 162 & 157 & 155 & 170 \\
\hline
\end{tabular}


According to Index of Economic Freedom, business, trade and fiscal freedom are all above the world average, while financial, investment, property and freedom from corruption are far below (Miller and Kim 2015). In fact, while the indicator of fiscal freedom in Russia has one of the highest scores meaning that the tax burden is relatively low, the perceived effect of tax burden is reported to be by far the most important obstacle for local entrepreneurs (World Bank 2012). The objective indicator measured as a total amount of collected taxes does not reflect in similar corresponding subjective perceptions of entrepreneurs, thus pointing towards the existence of the substantial gap between the objective and measurable reality and subjective perceptions about this reality. Another interesting fact is that, although the Index of Economic Freedom shows that trading freedom (a composite measure of the absence of tariff and non-tariff barriers that affect imports and exports of goods and services) has been gradually improving and by 2014 has reached levels of the most developed economies (Miller, Holmes, and Feulner 2013), this has not lead to any increase in rates of entrepreneurial internationalization in Russia. It can be suggested that the reason for this may lay in informal institutions; while there are many rankings and reports dealing with formal institutional frameworks, informal institutions are not easily measurable. At the same time, according to another study, as much as sixty percent of economic activities in emerging economies are driven by informal institutions including values, norms and beliefs spread in a society (Webb et al. 2009). While there are many other inconsistencies between statistical indicators and real life experiences, we clearly see the relevance for our study in trying to provide evidence-based explanations. The next section describes our methodological approach in filling the gaps on the crossroads of international entrepreneurship and institutions as it is experienced by entrepreneurs. 


\section{Methodology}

To gain greater insights and investigate in more detail the impact of institutional environment on entrepreneurial growth and internationalization as it is experienced by practicing entrepreneurs in Russia, we rely on hermeneutic (interpretive) phenomenology (Heidegger 1962) as a philosophical and methodological standpoint guiding this study. While there are many definitions and conceptualizations of phenomenology offered by different scholars they all agree that phenomenology has the "potential to penetrate deep to the human experience and trace the essence of a phenomenon and explicate it in its original form as experienced by the individuals" (Kafle 2011, 183). Generally, "a phenomenological study is one that focuses on descriptions of what people experience and how it is that they experience what they experience" (Patton 2015, 117). The hermeneutic (interpretive) version of phenomenology differentiates itself from the pure phenomenology in a way that it allows for interpretation of the lived experiences rather than providing mere descriptive accounts. In so doing, it focuses on people's meaning of a lived experience of a focal phenomenon in order to describe the essence of experiencing the phenomena (Seymour 2007). Thus, this particular philosophical and methodological stance has clear correspondence with the purpose of this study and provides guidelines for the subsequent data collection and analysis (Berglund 2007; Cope 2005). Additionally, phenomenology allows to integrate within one study intra-individual cognitions with extra-individual discourses (Berglund 2015), thus illuminating both individual cognitions and institutionally-transmitted discourses. The current study employs a qualitative methodology seeking for "better stories, not better constructs" (Dyer and Wilkins 1991, 613), although operating with extensive quantity of interview data. The phenomenological focus of this qualitative inquiry implies getting at the essence of the experience 
of how institutional environment affect growth and internationalization of Russian ventures through analyzing interviews with entrepreneurs.

\section{Description of data}

The phenomenological research approach implies bracketing all the preconceived knowledge on the phenomenon at the stage of data collection. In our study, the interviews were conducted by other practicing entrepreneurs before the study was initiated, thus naturally preventing the bias of pushing theoretical perspectives towards interviewees. The data came from two publically available series of videotaped interviews with entrepreneurs conducted by two other practicing entrepreneurs. The interviews were not meant to be organized for the purpose of the current research, hence the data is a secondary source with a disadvantage of being less specific to our research needs. This disadvantage is being overcome by analyzing the voluminous number of interviews and the fact that for Russian entrepreneurs it is hardly possible to avoid topics related to institutions no matter how general the interview itself is. The data analysis confirmed our presumption on this matter. Another advantage of the data is that interviews were conducted by entrepreneurs themselves in a friendly and open-way manner, whereas their guest were ready to share their lived experience honestly and deliver rather sensitive information. Some of interviewees are their friends, some belong to "big names" of Russian business or to young generation of entrepreneurs. The first set of records contains 146 interviews (BS1 to BS146) held from October 2009 to September 2013, while the second set, consisting of 67 interviews (MD1 to MD67), was recorded between May 2014 and September 2015. Thus, the core data for this study contains 213 transcribed interviews, 116 hours of records and 1290 pages of transcripts. Importantly, these series were shot in two temporally sequential but rather distinct intervals when considering institutional environment in Russia. The former timeframe, when the first series were shot, started right after 
the revival from the global economic crisis of 2008 and belongs to generally untroubled presidency of Dmitry Medvedev who was relatively liberal towards entrepreneurship. The latter period under the presidency of Vladimir Putin refers to sharply decreased oil prices, armed conflict in Ukraine and related two-way trade sanctions between Russia and Western World, which all have had negative influence on Russian economy. Among interviewees, we not only have Russian entrepreneurs of different age, gender and scale, but also investors, government representatives and foreign entrepreneurs doing business in Russia, thus providing opinions from different perspectives (Table 2).

Table 2. Classification statistics $(\mathrm{N}=213)$

\begin{tabular}{|c|c|c|c|c|c|c|c|}
\hline Scale & $\%$ & Experience & $\%$ & Age group & $\%$ & Gender & $\%$ \\
\hline Local & 68 & Business & 75 & Younger (born after $1973^{1}$ ) & 40 & Male & 90 \\
\hline National & 9 & International & 30 & Older (born before 1973) & 60 & Female & 10 \\
\hline International & 9 & & & & & & \\
\hline Global & 14 & & & & & & \\
\hline
\end{tabular}

The majority of interviewees were born in Russia, while 19 of others are from former Soviet Union countries and 10 are foreigners. The average age at the date of interview is 39.5 years that matches the latest figures from Global Entrepreneurship Monitor report on Russia (Verkhovskaia and Dorokhina 2014). Gender distribution reflects the dominance of males in entrepreneurship, corresponding with secondary data (Verkhovskaia and Dorokhina 2014).

\section{Data analysis}

In our analysis, we investigate the influence of institutional environment on venture creation, growth and internationalization as it is reflected in experience, attitudes and perceptions of acting entrepreneurs. In order to organize and analyze the large amount of information we utilized a Computer Assisted Qualitative Data Analysis Software package, in our case NVIVO 11. In our analysis we followed guidelines for phenomenological research approach (Giorgi 1985; van 
Manen 1990; Smith et al. 1999), that were also applied in other studies into entrepreneurship (Berglund 2007; Cope 2005, 2011).

In overall, our analysis included five basic steps. The first step involved watching the full set of videos in order to obtain "a sense of the whole of the phenomenon as described. The second step generally referred to as horizonalization implied more thorough analysis of individual interviews and corresponding transcripts with the aim to extract and label all the significant statements (meaning units) related to the experience of the focal phenomenon. The third step was grouping and categorization of isolated meaning units into thematic categories (clusters of meanings), where categories with similar meanings were merged and others split up in the process. This step was finished when all the significant statements were assigned to some category. On the fourth step, the identified categories were grouped into factors, while factors were further reduced to dimensions where possible. The final step was interpretation and synthesis of the combined evidence leading to what we have reported in the results section. Each table presented in the results section contains selected illustrative quotations from our interviews, while conclusions are made only if the same pattern is repeatedly supported within the entire set of interviews. To be able to meaningfully interpret the data and integrate the results with the existing body of knowledge, available academic studies and external research reports about entrepreneurship in Russia and institutional factors involved in entrepreneurship such as Global Entrepreneurship Monitor and World Bank Doing Business reports were taken into consideration; hence, the findings of our study were discussed in order to address particular problematic issues with aggregate figures from the secondary reports and explain surprising research results obtained elsewhere (Volchek, Jantunen, and Saarenketo 2013). 


\section{Results and discussion}

\section{Towards an integrative framework of entrepreneurial cognition}

The results and discussion section is largely based on provided direct quotations, which are responsible for delivery of a thick description contributing to the trustworthiness of the study (Lincoln and Guba 1985). Having multiple supporting evidence, our analysis shows that there is a discrepancy between attitudes and behavior based on personal experience versus those framed by external institutional factors (see Table 3). Similar pattern or relationships between cognition framed on the basis of personal experience compared with that mostly based on institutionallyshared knowledge is also persistent in the following parts of our analysis. Particularly, in most cases, when entrepreneurial cognitions are based on personal experiences they reflect more positive attitudes towards venture creation, domestic growth and internationalization, while institutionally transmitted knowledge and social pressures suggest abandoning these intentions. In other words, in a situation when nascent entrepreneurs do not have any or have only limited experience to frame their cognition, they have to overcome these affectively strong institutional pressures. Notably, very low perception of capabilities $(27.8 \%)$ corresponds to cultural-cognitive pillar and amplifies the negative effect from the above-mentioned social pressures (Singer, Amorós, and Moska 2015).

Table 3. Experience-based versus institutionally-driven cognition

\section{Experience-based cognition}

MD5: I think that all these fairytales about how difficult is to do business in China are very much subjective (entrepreneur actively developing his business in China)

MD3: Frankly speaking, I often do not understand when someone speak of a monstrous corruption in Russia. I have been in the business for the last 25 years and I do not remember that someone extorted money from me, despite I had experience of offering money myself to solve a

\section{Institutionally-driven cognition}

MD2: When we decided to start up, everyone told us that we are going to fail, that we don't have enough money to start up, that we live in our dreams. Even our parents told us that our idea is silly. Thereat I decided to take a strong step and stop talking to people who demotivate me.

BS32: It is pretty clear that what's yours here is not always yours, somebody can come and take it away... I think there are 
problem more optimally. I have faced with the bureaucracy in many countries, and I must say that ours is not the worst one. Here, in most cases, you can always reach an agreement, in contrast to i.e. France. For example, if you would like to start your own business you can easily establish sole proprietorship and get benefits such as reduced tax rates.

BS46: I think there is nothing so frightening to be afraid of doing business here. We are always frightened: there is a huge administrative burden, monstrous tax authority and other state agencies, but knock a wood, we have not had any problems with the state for all these ten years. I mean yeah, a lot of nonsense, but in general, it is not so difficult to do business in Russia as people think. rules, I think they are clear and I think if you do not work within those rules and boundaries, the state can come and take anything away.

BS53: When you try to discuss and share your business ideas to anyone else, first what you get in feedback are dozens of reasons of why you will fail. These negative attitudes are in the air and it somehow connected to education. If a person tries to do something its environment somehow subconsciously protect him from doing it.

In general, every entrepreneurial intention before implementation first goes through the cognitive

process of feasibility analysis that involves both personal experience and institutional pressures.

The following vivid story describes how experience helps to go through seemingly deterrent

burdens of regulative environment:

MD37: When I have just started this venture, every quarter I had discussions with tax inspectors. I was blamed in violations, and on my question what I was violating they stated that my venture is unprofitable and asked to explain why. I explained: "We have an investment project and our shareholders invested their money in the company. This money is consumed to create the product". - "No, you cannot do this; we have to call on the commission to analyze your behavior". Does it help? It seems to me not conducive at all. Of course, having had enough experience behind and, in particular, the experience in dealing with regulatory bodies, I did perceive the situation with humor: - "OK, let's have a commission and discuss it together. I'll listen to your suggestions how to lead out the company from such a terrible state when it does not bring profit from day one". I suppose someone without experience would be threatened to death by being called for commission and think he would better find a job.

Being threatened by such regulative pressures, a large number of people abandon starting entrepreneurial career in favor of having more stable job elsewhere, whereas institutionally encouraged careers are found in large state-affiliated enterprises, military or federal security services (BS10; MD37). As according to Global Entrepreneurship Monitor, the negative 
perceptions of the opportunities for venture creation and unfavorability of external environment, so extensively shared by non-entrepreneurs, could be halting the influx of new entrepreneurs; tackling this perception is therefore critical (Singer, Amorós, and Moska 2015). For potential entrepreneurs with legitimate business opportunity in mind and without previous experience the difficulty to overcome these pressures from informal institutions may prevent them from becoming entrepreneurs and leave them with good ideas that go unfulfilled. Interestingly, for entrepreneurs opportunities for venture creation and perception of favorability of external environment in Russia are more than twice higher than for non-entrepreneurs (Verkhovskaia and Dorokhina 2014), thus indirectly supporting our general idea that experience-based cognition is largely distinct from cognition that is solely based on institutionally-driven knowledge. The remaining part of the section is devoted to describe the impact of institutional environment on entrepreneurial intentions.

\section{Regulative institutions and collision with informal institutions}

Whilst public policy plays a major role for building favorable regulative conditions for entrepreneurship, constant changes in legislation, inconsistent and ambiguous laws hinder entrepreneurial activity (OECD 2005). Our study reveals that general attitude of entrepreneurs towards current lawmaking policies in Russia is that when developing particular laws related to their activities the government should better consult with business practitioners and entrepreneurs, because the laws are often seemed impractical. Despite of this attitude, our evidence shows that there is an enduring tendency to conform and at least formally adapt to a new legislation, though largely at the cost of end customers (see Table 4). 


\section{Conformity to impractical regulations at the cost of end customer.}

BS16: These days, the views of retail chains and manufacturers are ignored by law-makers, and legislators alone decide for the whole country how every price should be formed... They make mistakes, then slowly correct them, but in the end, as always, it is the end customer who pays for their mistakes.

BS21: Legislators don't have to understand all the intricacies of the business, because it is impossible for them. I do this 24 hours a day, and they - 20 minutes. It's normal that they do not understand retail, what upsets me the most is that they don't listen to the opinion of the professional players in the market.

MD56: Today, in my view, the state is the biggest risk for any entrepreneur. Personally, I got used to wake up thinking am I poor already or not yet? Because of legislative initiatives. Especially, in the field of beer ... For six years while I was brewing beer, many things happened. In general, the state is an everyday risk situation, with which we got used to live and find ways to resolve. We are preparing for the bad. Just in case if this law (forbidding plastic bottles for draft-beer shops) would be accepted, my friends from "Novosibirskprodmash" are developing an alternative solution.

\section{Lived experience refuting harsh regulative pressures}

MD47: So far, I have not felt any excessive demands of any pressure from tax and other authorities.

MD51: First, there are many empty niches, untilled field; second, there are almost no impediments from the government.

MD54: I've never felt any repressions from the tax authorities.

MD58: I've never experienced any problems with the authorities or with the law. I simply do not understand some of the discussion that there are obstacles.

An important observation is that entrepreneurs tend to complain about regulations in rather general terms without providing examples from their lived experience. At the same time, when it comes to practice, it feels like this negative institutionally-shared attitude towards regulative burden is exaggerated or even refuted by their lived experiences (see Table 6). Although, we have been able to find out few cases where entrepreneurs had to abandon the business because of the new regulations (e.g. when police reform made street trade restriction more enforced), in these cases it was not a fatal trouble and just a matter of time for entrepreneurs to reorient the business into more legitimate one or, in the worst scenario, to change the sphere (see Table 5). This result highlights the persistence of entrepreneurs relative to regulative burden. Specifically, the costs of regulative 
burden entrepreneurs are faced with in Russia are oftentimes paid by the end customers, not the entrepreneurs. This finding can serve as an explanation for insignificant impact of regulative institutions on SMEs' performance in Russia reported elsewhere (Volchek, Jantunen, and Saarenketo 2013). Other studies highlighted surprising persistence and resilience of entrepreneurs and their ventures through macroeconomic crises (Davidsson and Gordon 2016) and even danger of war (Bullough, Renko, and Myatt 2014). Thus, we can infer that the persistence can be regarded as a special quality attributable to (some) entrepreneurs. This capability to anticipate, adapt and adjust their business can be considered as dynamic capability of entrepreneurs in the realities of constant institutional changes relative to their sectors of economy ( Teece, Pisano, and Shuen 1997).

In our interviews, we have not been able to identify any first-hand evidence of severe regulative pressures ultimately affecting entrepreneurial actions. In particular, instead of revealing their own experience entrepreneurs were referring to vicariously learned knowledge (Kim and Miner 2007) based on exceptional cases and some gossip-like stories (i.e. social discourse). In few cases where there were some minor tensions with regulative bodies and negative complaints, entrepreneurs were able to respond in a conforming manner rather quickly and did not experience any dramatic consequences regarding their entrepreneurial actions (e.g. BS 10). Furthermore, we have to admit that our impression concerning these minor tensions with regulative environment is that if these entrepreneurs were more informed about laws, rules and practices before they made their actions, they would have easily avoided these problems. Additionally, we have found the evidence that even acting entrepreneurs sometimes lack rather basic knowledge related to establishing and operating new business (i.e. cultural-cognitive institutions as conceptualized by Busenitz et al. 2000), as you can see from the dialog below: 
MD4: Recently I have been trying to register a new enterprise in Moscow and it is just terrible. The prices for registration services are extremely high, it cost me ten times more than in St. Petersburg. Ten times!

Interviewer: Is it a simple limited company?

MD4: Yes.

Interviewer: Actually, you can do it free of charge.

MD4: Oh really? Where?

We can interpret the story above in a way that the knowledge about more efficient ways of establishing new business has not been institutionalized so far or in other words have not yet become a part of a shared social knowledge. Accordingly, we may infer that cultural-cognitive dimension of institutional environment collides with regulative institutions thus inhibiting efficiency of entrepreneurial activity in Russia. However, if the end customer is ready to pay for this inefficiency as a result of low level of industry-based competition, eventually it gives an entrepreneur a chance to survive and succeed. Likewise, there is also clear evidence that normative institutions may also undermine proper functionality of regulative framework. An interesting example how recent changes in formal institutional environment affected entrepreneurs in Russia happened in 2013, when the government decided to double the amount of tax-like pension and social insurance contributions. The consequence of this change was that more than five hundred thousand individual entrepreneurs closed their legal entities and presumably converted their businesses to black and gray markets (Safonov 2014). Notably, this kind of socially acceptable isomorphic collective behavior reflects the institutionalized practice of converting businesses to informal economy as opposed to abandoning it (DiMaggio and Powell 1983; March and Olsen 1989). One of our interviewee provide another similar example of how regulative changes may activate previously latent but easily awaken norm of going to and operating in the black market: 
BS6: I am sure that sooner or later gambling business will came back to Russia. In fact, it has never been closed. It has had to adjust, and the government eventually has got a huge illegal industry.

Influence of normative and cognitive institutional pillars in relation to regulative one and as main effect onto entrepreneurial intentions and behavior are examined in the next sections.

\section{Cultural-cognitive and normative institutions for entrepreneurship}

In relation to cultural-cognitive pillar of institutional environment, our data lead us to several important considerations. Different cultural values make people different in what is important for them, particularly in relations to their entrepreneurial intentions people from different cultural backgrounds put emphasis onto different things. For example, in more universalistic societies, the law is the law and if it is forbidden to pursue certain entrepreneurial opportunity, then people would most likely abandon their intention. In the particularistic society like Russia, the laws themselves are not so straightforward and entrepreneurs may find a way to go around or stay unnoticed (Hendley 2012). Non-universally inclusive nature of regulative institutional environment (e.g. arbitrary and non-mandatory provisions on law enforcement) was mentioned many times in our interviews and several entrepreneurs even referred to the same quotation by famous Russian 19thcentury satirist and ironically civil servant Mikhail Saltykov-Shchedrin (cited in Barber, Buckley, \& Belton, 2008):

'The severity of Russian laws is alleviated by the lack of obligation to fulfil them.'

Having in mind these particularistic social norms and values spread in the society, putting too much effort on building regulative environment at the cost of informal institutions seem to be inefficient. Maintaining costly high-standard and favorable legal framework pays off only where it actually works in practice. 
Another interesting observation concerns the norms related to the quality of produced goods and services. While the times when the Russian market was starving for whatsoever goods and services have passed, the experimental evidence from our interviews shows that comparing to various other countries in most industries there is low (or even no) competition for goods and services of proper quality. From the institutional perspective, this finding reflects the absence of normative institutions supporting and incentivizing delivery of high-quality goods and services. There are common idioms and jargons describing this kind of attitude such as 'people have it', 'grannies eat it' or 'people like it' in relation to any low-quality, but mass-market and commercially viable product, from music and programs to skim margarine and political agenda. In this view, majority of people here are thought to be unsophisticated and lacking any demand for better quality. Without arguing on the issue, we may blame historical path dependency and specifically the soviet period when people did not have any choice in what they consume and now when they are overwhelmed with variety of goods and services they are still in the initial stage of framing their preferences for quality:

MD11: People are still fine buying lower-quality goods, but when they start asking for quality then it will be different.

The following quotation vividly shows the segment with formed demand for sufficient quality from people of above average income who had the experience of proper level of service elsewhere:

MD45: Even when I come to the official BMW dealer in Moscow for ordinary maintenance, I have to give some money on top to ensure that they will put effort to make everything fine. That is because so often I had left the dealer not on my wheels, with different rugs, etc. I just want to be served OK. There is no need for wow-effects, no need to be surprised. What I need is a service that I pay for, nothing more! Just do not screw it up, come on time, call on time, deliver a product, call to find out if everything is in order - this level of service would make people said, 'Wow, it's unbelievable, how come you are so good?'

In our interviews, we have been able to find multiple experience-based evidence showing this kind of attitude, explicitly claiming that there are many niches where improved quality of goods and 
services would easily convert currently latent demand into a viable business. Alongside, many times in the interviews entrepreneurs have expressed simple heuristic that in order to stay safe from possible interventions of various powerful actors it is better to remain small and not stand out too much. Together with this normative constraints towards growth and visibility, there are also similarly working norms related to being politically active and doing business in some particular sectors of economy (Table 5).

Table 5. Normative institutions

\section{Normative constraints towards growth and visibility}

MD4: In Russia, the business can be done. I do not know, however, up to what volumes. Perhaps, my business have not yet reached the volumes that we would be interesting for a variety of parties, but in principle, they allow me to work.

MD20: ...I think no one bothered me much so far, and I hope that after your program, too, no one will...

MD47: When a business crosses some point in size and becomes interesting for those people who have the right to decide something in the bodies, perhaps there could be some questions and difficulties. At my level, it is easily possible to do business in Russia.

\section{Normative constraints towards political and sectoral activity}

MD 9: I think, if you do not meddle in politics and don't participate in dubious projects ... then the business can be conducted in Russia

MD 45: It's rather easy to do business here. If you do not cross the line interfering with the government and not striving for political power, they will be loyal to you.

Notably, we have not found any practical experiences of entrepreneurs sharing their own real-life stories describing how growth and visibility made them more exposed to opportunistic attention from the authorities. Table 5 also highlights the dissonance between real experience and institutionally shared opinion, where an entrepreneur presupposes what could happen based on some common knowledge, without providing their own lived experience.

Notably, while the attitudes for growth-constraining norms were found in both samples of interviews, restrictions on political and sector-specific activities mentioned in the second set of 
interviews were extended to additional spheres. Whereas previously the restrictions concerned mostly the oil and gas sector of economy and political activities at the highest levels (e.g. Mikhail Khodorkovsky case), the second set of interviews revealed the expansion of this institutional norm to other sectors of economy (e.g. related to national informational security) and increased opportunities for local officials to intervene local enterprises. Hence, our analysis point to the development or expansion of normative institutions constraining entrepreneurial actions in particular sectors of economy and increased political pressure.

\section{Institutional determinants of entrepreneurial internationalization}

Comparison of internationally-active entrepreneurs with national and local ones allowed us to highlight several important differences. While in the cohort of domestic entrepreneurs featured both necessity- and opportunity-driven entrepreneurs in rather equal shares, international entrepreneurship in our sample predominantly implies opportunity-driven motives. Furthermore, international entrepreneurs were more talking about competitive characteristics of their offerings, rather than about regulative constraints and obstacles.

The perception of the harsh domestic institutions may eventually push the firm to internationalize and search for internationalization assistance from abroad. As in the case mentioned before, when a person had to start a private school because he was unable to realize his idea within rigidly regulated public schools, negative "push forces" from regulative environment may lead entrepreneurs to establish a business abroad (Table 6). 
Table 6. Institutional escapism

\section{Exemplary evidence}

MD48: I have another hobby I want to bring to life, it is moonshining. I am planning to open up a factory for the production of spirits. The only thing is it is impossible in Russia, because the licensing is very complex, so in the near future the plan is to start in one of the neighboring countries.

MD21: I think that even in IIDF ${ }^{2}$ they understand that the realities of Russian law are such that it is very difficult to enter the company and somehow arrange the relationship between the shareholders. It is just impossible to do so in the way that everyone would be satisfied and without dramatic ending. Today, of course, it is better to work under English law jurisdiction, but I hope all this will change for the better in one, two of three years.

The above-mentioned tendency of institutional escapism in order mitigate the poor institutional contexts have been attributed to countries with institutional voids in their home country institutional contexts (Witt and Lewin 2007; Yamakawa, Peng, and Deeds 2008). While internationalization due to institutional escapism has negative consequences on national economy and leads to brain drain, the government should provide opportunities for efficient international operations while keeping these ventures within legal boundaries of the country.

Noteworthy, while general entrepreneurship and SME support programs have been discussed to have positive impact on venture creation multiple times in the interviews, internationalization support agencies or practices have never been mentioned. This may stem from the fact that Russian formal institutions do not provide much support for the internationalization or entrepreneurs driven by informal institutions don't bother knowing about available support or feel better avoiding it. They may feel that there is no need to use national support organizations (Bell 1997), or they may think that primary information from the market is more beneficial (Seringhaus 1987).

\section{Conclusions and further research}

Existing research on institutional theory in the fields of entrepreneurship (Bruton, Ahlstrom, and Li 2010), international business (Jackson and Deeg 2008) and its intersection - international 
entrepreneurship (Szyliowicz and Galvin 2010) is lacking studies which focus on informal (normative and cultural-cognitive) dimensions of institutional environment. This study aimed at comprehensive analysis of practically relevant institutional factors regarding major entrepreneurial decisions such as venture creation, growth and internationalization. Through the course of our analysis we were able to examine elements of institutional environment relevant to particular entrepreneurial intentions, as acting entrepreneurs perceive these.

Main contribution of our study stems from building a general model for entrepreneurial cognition based on experience and institutions, and from deepening existing knowledge on intertwined influences of various institutional combinations on entrepreneurship and internationalization (Figure 1).

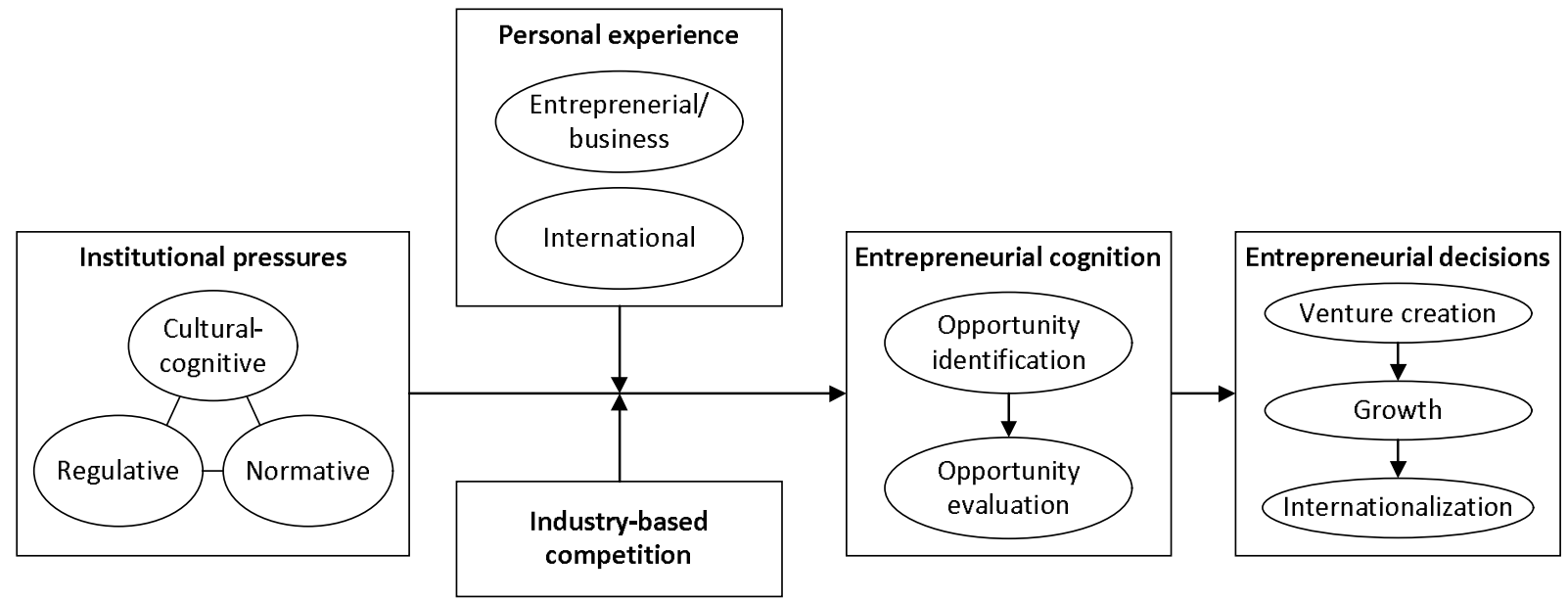

Figure 1. An integrative model of entrepreneurial cognition

The aforementioned framework was gradually developed through synthesizing the knowledge from the available evidence persistent throughout all sections of conducted analysis. The model implies that before making a particular decision (venture creation, growth and internationalization) entrepreneurs evaluate previously identified opportunity through the prism of their own experience as well as against expectations from the institutional environment. This mechanism of cognitive 
assessment embodies an interesting duality between institutionally shared opinions and own experiential knowledge of entrepreneurs if the latter is present. Supported by the analysis of 213 interviews, the study propose that the impact of institutional pressures on entrepreneurial cognitions is moderated by entrepreneurial experience and level of industry-based competition. In other words:

Proposition 1: The more experience an entrepreneur has, the lower the negative impact of institutional pressures on his cognitions regarding intentions to create, expand and internationalize their venture.

Proposition 2: The higher the level of industry-based competition, the lower the negative impact of institutional environment on entrepreneurial cognitions regarding intentions to create, expand and internationalize their venture.

Implementation of policies according to the abovementioned propositions should decrease and alleviate the negative consequences of domestic institutional environment, thus triggering new venture creation and entrepreneurial internationalization. Likewise, the study shows that the negative impact of institutional environment largely stems from informal institutions, such as unsupportive social pressures towards entrepreneurship and various normative and culturalcognitive constraints. Additionally, our analysis revealed an intertwined impact of particular institutional factors, thus emphasizing the need to study institutional environment as a set of configurations ("bundles") rather than trying to separate the impact of certain institutional factors or dimensions. Besides, the currently absent trust between entrepreneurs and the government is a high-priority challenge to overcome in order to enhance efficiency of implemented policy measures and improving regulative framework. The fact that governmental support relative to internationalization activities has never been mentioned may also be due to the lack of trust and deliberate attempt to hide from the 'radar' until ventures become more independent (institutional escapism). 
While our phenomenological analysis does not allow us to generalize the results to other countries in the statistical sense, we have shown that more nuanced context-sensitive approach to institutional forces relevant for entrepreneurs in relations to their intentions to create, grow and internationalize their ventures brings deeper and more practice-oriented understanding. By providing examples how formal institutional forces interact with informal, eventually turning towards an opposite direction than it was expected on the basis of "theory", we warn policy-makers from transition economies like Russia, where formal and informal institutions are not aligned, against any simplistic and partial benchmarking. Alternatively, they should carry out more tailored and nuanced measures that fit to a particular country. In this respect, research may further look onto different configuration of institutional factors to identify congruent patterns valid across countries (Puffer, McCarthy, and Boisot 2010). Despite the fact that discussions of specific politicaleconomic reforms go beyond the boundaries of this study, we have been able to show that policies directed to promotion of entrepreneurial experience, increased competition and supportive informal institutions must be regarded as an inevitable part of institutional changes in Russia. More harmonized development of institutional environment that encompasses particular combinations of factors conducive towards entrepreneurship would help to utilize currently hampered potential of Russian economy. 


\section{References}

Aidis, Ruta, Saul Estrin, and Tomasz Mickiewicz (2008), "Institutions and Entrepreneurship Development in Russia: A Comparative Perspective." Journal of Business Venturing 23(6): 656-72.

Alon, Ilan, and Daniel Rottig (2013), "Entrepreneurship in Emerging Markets: New Insights and Directions for Future Research." Thunderbird International Business Review 55(5): 487-92.

Atkins, Ralph (2012), "Judging Economic Performance in the G20." Financial Times. https://www.ft.com/content/6af76b28-3320-11e2-aa83-00144feabdc0.

Barber, L., N. Buckley, and C. Belton (2008), "Laying down the Law: Medvedev Vows War on Russia's 'legal Nihilism.'” Financial Times. www.ft.com/int1/cms/s/0/4b93ecde-f9c3-11dc9b7c-000077b07658.html\#axzz3zKjGoOAc.

Bell, Jim (1997), "A Comparative Study of the Export Problems of Small Computer Software Exporters in Finland, Ireland and Norway." International Business Review 6(6): 585-604.

Berglund, Henrik (2007), "Researching Entrepreneurship as Lived Experience." In Handbook of Qualitative Research Methods in Entrepreneurship, eds. Helle Neergaard and John P. Ulhoi. Cheltenham, UK: Edward Elgar Publishing, 75-94.

Berglund, Henrik (2015), "Between Cognition and Discourse: Phenomenology and the Study of Entrepreneurship" ed. Dr David Higgins, Professor Kiran Treh. International Journal of Entrepreneurial Behavior \& Research 21(3): 472-88.

Bruton, Garry D., David Ahlstrom, and Han Lin Li (2010), "Institutional Theory and Entrepreneurship: Where Are We Now and Where Do We Need to Move in the Future?" Entrepreneurship: Theory and Practice 34(3): 421-40.

Bullough, Amanda, Maija Renko, and Tamara Myatt (2014), "Danger Zone Entrepreneurs: The Importance of Resilience and Self-Efficacy for Entrepreneurial Intentions." Entrepreneurship Theory and Practice 38(3): 473-99.

Busenitz, Lowell W., Carolina Gómez, and Jennifer W Spencer (2000), "Country Institutional Profiles: Unlocking Entrepreneurial Phenomena." Academy of Management Journal 43(5): 994-1003.

Cope, Jason (2005), "Researching Entrepreneurship through Phenomenological Inquiry: Philosophical and Methodological Issues.” International Small Business Journal 23(2): 16389.

Cope, Jason (2011), "Entrepreneurial Learning from Failure: An Interpretative Phenomenological Analysis." Journal of Business Venturing 26(6): 604-23.

Davidsson, Per, and Scott R. Gordon (2016), "Much Ado About Nothing? The Surprising Persistence of Nascent Entrepreneurs Through Macroeconomic Crisis." Entrepreneurship Theory and Practice 40(4): 915-41.

DiMaggio, Paul J., and Walter W. Powell (1983), “The Iron Cage Revisited: Institutional Isomorphism and Collective Rationality in Organizational Fields." American Sociological 
Review 48(2): 147.

Dyer, W. Gibb, and Alan L. Wilkins (1991), "Better Stories, Not Better Constructs, to Generate Better Theory: A Rejoinder to Eisenhardt." Academy of Management Review 16(3): 613-19.

Giorgi, Amedeo (1985), Phenomenology and Psychological Research. Pittsburgh, PA: Duquesne University Press.

Heidegger, Martin (1962), Being and Time. Harper and. New York, NY.

Hendley, Kathryn (2012), "Who Are the Legal Nihilists in Russia?" Post-Soviet Affairs 28(2): 14986.

Jackson, Gregory, and Richard Deeg (2008), "Comparing Capitalisms: Understanding Institutional Diversity and Its Implications for International Business." Journal of International Business Studies 39(4): 540-61.

Kafle, Narayan Prasad (2011), "Hermeneutic Phenomenological Research Method Simplified." Bodhi: An Interdisciplinary Journal 5(1): 181-200.

Kim, Ji Yub, and Anne S. Miner (2007), "Vicarious Learning from the Failures and near-Failures of Others: Evidence from the U.S. Commercial Banking Industry." Academy of Management Journal 50(3): 687-714.

Lincoln, Yvonna S., and Egon G. Guba (1985), Naturalistic Inquiry. Beverly Hills, CA: SAGE Publications, Inc.

van Manen, Max (1990), Researching Lived Experience: Human Science for an Action Sensitive Pedagogy. Albany, NY: State University of New York Press.

March, James G, and Johan P Olsen (1989), Rediscovering Institutions: The Organizational Basis of Politics. New York, NY: The Free Press.

Miller, Terry, Kim R. Holmes, and Edwin J. Feulner (2013), Index of Economic Freedom. Washington, DC: The Heritage Foundation and Dow Jones \& Company. http://www.heritage.org/index/pdf/2013/book/index_2013.pdf.

Miller, Terry, and Anthony B. Kim (2015), Index of Economic Freedom: Promoting Economic Opportunity and Prosperity. Washington, DC: The Heritage Foundation and Dow Jones \& Company. http://www.heritage.org/index/pdf/2015/book/index_2015.pdf.

OECD (2005), OECD SME and Entrepreneurship Outlook 2005. Paris, France: OECD Publishing. http://www.oecd-ilibrary.org/industry-and-services/oecd-sme-and-entrepreneurship-outlook2005-edition_9789264009257-en.

OECD (2015), "SMEs and Entrepreneurship in the Russian Federation." In Russian Federation: Key Issues and Policies, Paris, France: OECD Publishing, 47-64. http://www.oecdilibrary.org/industry-and-services/russian-federation-key-issues-and-policies/smes-andentrepreneurship-in-the-russian-federation_9789264232907-6-en.

Patton, Michael Quinn (2015), Qualitative Research and Evaluation Methods. 4th ed. Thousand Oaks, CA: SAGE Publications, Inc. 
Puffer, Sheila M., Daniel J. McCarthy, and Max Boisot (2010), "Entrepreneurship in Russia and China: The Impact of Formal Institutional Voids." Entrepreneurship Theory and Practice 34(3): 441-67.

Safonov, Sergey (2014), Small and Medium Entrepreneurship in Russia. Luxembourg. http://www.eib.org/attachments/efs/econ_study_small_and_medium_entrepreneurship_in_ru ssia_en.pdf.

Seringhaus, Rolf (1987),. "The Role of Information Assistance in Small Firms' Export Involvement." International Small Business Journal 5(2): 26-36.

Seymour, Richard G. (2007), "Hermeneutic Phenomenology and International Entrepreneurship Research.” Journal of International Entrepreneurship 4(4): 137-55.

Singer, Slavica, Jose Ernesto Amorós, and Daniel Moska (2015), Global Entrepreneurship Monitor Global Entrepreneurship Monitor - 2014 Global Report. http://gemconsortium.org/docs/download/3616.

Smith, Jonathan, Virginia Eatough, Maria Jarman, and Mike Osborn (1999), "Doing Interpretative Phenomenological Analysis.” In Qualitative Health Psychology, 35-51.

Szyliowicz, Dara, and Tiffany Galvin (2010), “Applying Broader Strokes: Extending Institutional Perspectives and Agendas for International Entrepreneurship Research." International Business Review 19(4): 317-32.

Teece, David J, Gary Pisano, and Amy Shuen (1997), "Dynamic Capabilities and Strategic Management." Strategic Management Journal 18(7): 509-33.

Valdez, Michael E., and James Richardson (2013), "Institutional Determinants of Macro-Level Entrepreneurship." Entrepreneurship Theory and Practice 37(5): 1149-75.

Webb, Justin W., Laszlo Tihanyi, R. Duane Ireland, and David G. Sirmon (2009), "You Say Illegal, I Say Legitimate: Entrepreneurship in the Informal Economy." Academy of Management Review 34(3): 492-510.

Verkhovskaia, Olga, and Maria Dorokhina (2014), Global Entrepreneurship Monitor: Russia 2013 (in Russian). St.Petersburg, Russia: Graduate School of Management. http://www.gemconsortium.org/report/49153.

Witt, Michael A, and Arie Y Lewin (2007), "Outward Foreign Direct Investment as Escape Response to Home Country Institutional Constraints." Journal of International Business Studies 38(4): 579-94.

Volchek, Daria, Ari Jantunen, and Sami Saarenketo (2013), "The Institutional Environment for International Entrepreneurship in Russia: Reflections on Growth Decisions and Performance in SMEs." Journal of International Entrepreneurship 11(4): 320-50.

Volchek, Daria, Sami Saarenketo, and Ari Jantunen (2015), "Structural Model of Institutional Environment Influence on International Entrepreneurship in Emerging Economies." In Institutional Impacts on Firm Internationalization, ed. Svetla Marinova. London: Palgrave Macmillan UK, 190-216.

World Bank (2012), Enterprise Surveys: Russian Federation Country Profile. Washington, DC. 
http://www.enterprisesurveys.org/ /media/GIAWB/EnterpriseSurveys/Documents/Profiles/ English/Russia-2012.pdf.

World Bank (2016), "Doing Business 2016: Measuring Regulatory Quality and Efficiency. Economic Profile 2016." Washington, DC: World Bank Group. http://www.doingbusiness.org/ /media/GIAWB/Doing Business/Documents/AnnualReports/English/DB16-Full-Report.pdf.

Yamakawa, Yasuhiro, Mike W. Peng, and David L Deeds (2008), "What Drives New Ventures to Internationalize from Emerging to Developed Economies?" Entrepreneurship Theory and Practice 32(1): 59-82.

\footnotetext{
${ }^{1}$ The arbitrary year 1973 is chosen as year of birth for people who turned 18 at 1991 (collapse of the USSR)

${ }^{2}$ The Internet Initiatives Development Fund (IIDF) is a Russian venture capital fund established by the Agency for Strategic Initiatives as it was suggested by Vladimir Putin. The Foundation invests in technology companies in the early stages of development, develops a network of start-up accelerators, and is involved in the development of methods of legal regulation of the venture industry.
} 